\title{
АКТУАЛЬНІСТЬ ПРОБЛЕМИ ЛЕПТОСПІРОЗУ У ДІТЕЙ
}

\author{
Вінницький національний медичний університет ім. М.І. Пирогова
}

Наведено відомості про захворюваність лептоспірозом у Вінницькій області, клінічні особливості цієї недуги у дітей, приклад геморагічного лептоспірозу, який закінчився летально.

Ключові слова: лептоспіроз, діти, захворюваність.

Лептоспіроз належить до розповсюджених хвороб природно-осередкового характеру. Реєструється у 80 країнах світу, на всіх континентах, включаючи Антарктиду. В Україні щорічно реєструється у вигляді спорадичних випадків, рідко - спалахи.

У Вінницькій області, починаючи з 1994 р., щорічно засріксовано біля 22-26 захворювань лептоспірозом, захворюваність складала 1,5-1,8 на 100 тис. населення.

Упродовж 1994-2014 рр. у Вінницькій області захворіли на лептоспіроз 47 дітей, з них 40 лікувалися в м. Вінниця - ВОкдІЛ. Переважали діти віком старше 7 років - 31 $(17,6 \%)$, хлопчики - 36 (90,0 \%). Домінував водний шлях зараження, пов'язаний з купанням дітей в забруднених водоймах у липні-серпні; рідше - з вживанням інорікованих продуктів харчування, заражених сірими пацюками.

До стаціонару направляли дітей з діагнозами: ГРВІ, вірусного гепатиту, ентеровірусної інорекції, пневмонії, єрсиніозу, колагенозу.

У всіх дітей захворювання розпочиналося гостро, спостерігалися прояви загальної інтоксикації, підвищення температури до 38-39 С упродовж 5-9 днів. Характерними були: біль голови, адинамія, болі в литкових м'язах, шиї, животі, попереку, очних яблуках. У 17 дітей була вражена печінка, спостерігалася жовтяниця (50\%), на 3-й день хвороби підвищувалися білірубін (35,0 \%), АлАТ (27,0 \%), клініка менінгіту спостерігалася у 5 хворих (12,5\%).

Зміни в периферичній крові (нейтрофрільний лейкоцитоз, зсув формули вліво) відзначалися у 24 хворих (76,0 \%), в сечі (протеїнурія, гематурія, циліндрурія) - у 19 дітей (47,5 \%). При тяжкому перебігу лептоспірозу розвивався геморагічний синдром з блюванням «кавовою гущею», появою на шкірі петехіальної висипки, явищами склериту, кон'юктивіту.

Діагноз лептоспірозу був підтверджений РМА в 1 дитини 3 L. tarassovi та у другої - 3 L. javanica $(2,5 \%), ~ 3$ L. pyrogenes - y 4 (10,0\%), 3 L. canicola - y $3(7,5 \%) ; 3$ L. hebdomadis - 11 (27,5\%); 3 L. grippotyphosa - 13 (32,5\%); з L. icterohaemorrhagiae - 7 (17,5\%). Тяжкий перебіг спо- стерігався у 4 дітей, спричинений L. icterohaemorrhagiae, в 1 - L. hebdomadis, в 1 - L. canicola, y $2-$ L. grippotyphosa. Найтяжчим був перебіг геморагічного лептоспірозу, який закінчився летально у 2 хлопчиків.

У 2014 р. спостерігали дитину 16 років, хлопчик захворів гостро, температура $39{ }^{\circ} \mathrm{C}$ (приймав ліки самостійно). На 3-й день захворювання госпіталізований у ВОДЛ з підозрою на апендицит, хірургічна патологія була виключена. Наступного дня температура знову піднялася до $39^{\circ} \mathrm{C}$, було повторне блювання, з'явилася жовтяниця.

Госпіталізований на 5-й день хвороби у ВОКДІЛ з діагнозом вірусний гепатит. Враховуючи скарги на незначні болі в гомілкових м'язах (купався в озері), дані лабораторних досліджень крові (виражений лейкоцитоз з нейтрофрільозом), сечі (лейкоцитурія, поодинокі циліндри), загальний білірубін 158,7 ммоль/л за рахунок прямого, АлАТ 4,25 ммоль/л - встановлений клінічний діагноз лептоспіроз, тяжкий перебіг.

Проводилась активна антибактерійна, інфрузійна терапія (контривен, контрикал, свіжозаморожена плазма), симптоматична терапія. Стан дитини, незважаючи на проведену терапію, продовжував погіршуватись, з'явилася поліорганна недостатність. Захворювання ускладнилося ГНН з олігоурією, ДВЗ-синдромом, фраза гіпокоагуляції, набряком головного мозку з вклиненням у великий потиличний отвір, що закінчилося смертю на 9-й день захворювання.

Наслідки лептоспірозу, особливо іктерогеморагічного, залежать від знання епіданамнезу, ранньої діагностики захворювання, своєчасного застосування етіотропної та патогенетичної терапії.

\section{PROBLEM ACTUALITY OF CHILDREN LEPTOSPIROSIS}

I.I. Nezhoda, V.M. Yuzhanina

SUMMARY. Incidence of leptospirosis in the Vinnytsia region is describe, the clinical features of this disease in children, an example of hemorrhagic leptospirosis, which lethally.

Key words: leptospirosis, children morbidity.

Отримано 16.11.2015 р. 